\title{
Decision Support System for Rewarding Courier Employees in North Jakarta Using Profile Matching
}

\author{
Randy Teguh Waluya Nugraha*, Budi Arifitama*, and Yaddarabullah* \\ *Universitas Trilogi \\ Program Studi Teknik Informatika \\ Jl. TMP Kalibata No.1, Jakarta 12760, Indonesia \\ E-mail: budiarif@trilogi.ac.id
}

\begin{abstract}
Abstrak
Kurir merupakan bagian dari karyawan merupakan aset penting bagi perusahaan ekspedisi yang memiliki perhitungan capain kerja yang berbeda dengan karyawan biasa. Setiap Kurir memiliki kinerja produktivitas harian dengan target skor sempurna (100\%) untuk mendapatkan sebuah reward. Namun, penilaian yang hanya berdasarkan pada kinerja produktivitas menyebabkan permasalahan, di mana tidak mungkin seorang kurir dapat mencapai skor produktivitas yang sempurna untuk mendapatkan imbalan. Fokus penelitian ini adalah untuk memperbaiki sistem penghargaan dengan menggunakan sistem pendukung keputusan, dengan menambahkan aspek lain selain produktivitas yaitu aspek perilaku. Absen, pengiriman, cash on delivery, update status, kehadiran, dan keterlambatan. Metode Profile Matching dilakukan untuk membandingkan profil karyawan dengan nilai standar dan menghitung GAP-nya. Semakin kecil GAP, semakin besar bobot hasil untuk solusi alternatif terbaik. Hasil dari penelitian ini adalah, dari 150 karyawan, terpilih 5 karyawan sebagai karyawan terbaik dan diberikan penghargaan dengan skor posisi tertinggi 4.733, peringkat kedua 4.722, ketiga 4.722, keempat 4.721, dan kelima 4.721. Metode Profile Matching terbukti sebagai metode sistem pendukung keputusan yang baik untuk memberi penghargaan kepada karyawan berdasarkan peringkat.
\end{abstract}

Kata kunci: Sistem Pendukung Keputusan, Promosi Karyawan Kurir, Profile Matching

\begin{abstract}
Courier employees in an expedition company are an important asset for the company. Each Courier has a daily productivity performance to aim with a perfect score (100\%) to gain a reward. However, an assessment based only on productivity performance cause problems, where it is impossible to achieve a perfect productivity score to get a reward. This research focus to improve the rewarding system using a decision support system by adding other aspects than productivity which is the behavioral aspect. Absentee, successful delivery, cash on delivery, status update, attendance, and lateness are the behavioral aspect criteria used. Profile Matching method is conducted to compare employee profiles with the standard values and calculate its GAP. The smaller the GAP, the greater the weight results for the best alternative solution. The results, from 150 employees, 5 employees were selected as the best employees and granted rewards with the highest position scored 4,733, second scored 4,725, third scored 4,7234 , fourth scored 4,722, and fifth scored 4,721. Profile matching has proven to be excellent as a method for a decision support system to reward employees based on ranking.
\end{abstract}

Keywords: Decision Support System, Courier Employee Reward, Profile Matching

\section{Introduction}

Human resources is one of the most important elements for a company. A good human resources management will lead to better employee performance and productivity for the company. To maintain the stability of employee performance, an expedition company located at North Jakarta provides monthly rewards to the five top best employees with several assessment selections such as absentee, successful delivery, cash on delivery, status update, attendance, and lateness for behavioral aspect criteria. The reward is in the form of a shopping voucher of $\mathrm{Rp}$. 500,000 per month. To get the reward, the employee must fulfill 2 aspects of the assessment. The first 
aspect is the productivity aspect in the form of the total value of productivity and aspects second is the aspect of behavior in the form of criteria according to the assessment standards of companies namely absence, successful Cnote, Cash On Delivers (COD) payments, application updates, absences (in-out), and delays. Data criteria in this study obtained is based on the results of interviews with the manager of the company branch located in Sunter with reference to the standard company value. However, to determining rewards for the best employees that is less than optimal, because the total of employee reaching an amount of 150 employee data, that makes decisions slow and less precise. Therefore, we need a Decision Support System (DSS) for assisting managers in selecting the best employees. Decision Support System (DSS) is a flexible, interactive, computer-based information system and adaptable, developed to support solutions to problems unstructured specific management. Several studies in the field of a decision support system[1],[2] have been conducted such as for selecting student interest-based on curriculum[3] where an expert system is used as a comparison method to find best alternatives solution, then research in the field of gamification [4] where a multi criteria decision-maker is implemented to improve an artificial agent in immersive mobile technology[5]. In this research, Profile Matching method is used for an employees assessment selection to provide a comparison between the employee's value and the company's standard value[6],[7] and it is also proven able to select the best alternative from several alternatives[8],[9][10]. Based on the problem stated, the research is to develop a decision support system for selecting the best employees using the Profile Matching method, which can help provide convenience for company managers in determining the best employees who deserve to get rewards.

\section{Research Method}

\section{A. Profile Matching Method}

Profile Matching is an effective method for simplifying the decision making in an organization, where individual are compared based on different competencies usually known as GAP, the smaller the GAP produced, the greater the weight values, which resulted in a ranking position for the suited employees[11],[12]. Following is the GAP formula of performing the different competencies comparison show on (1).

$$
\text { Gap = Value of Employee Profile }- \text { Standard Value Profile }
$$

Then calculate the Core factors and Secondary Factors can be seen below (2) (3):

$$
N C F=\frac{\sum N C}{\sum I C}
$$

$\mathrm{NCF}=$ Average Core Factor Value

$\mathrm{NC}=$ Total of Core Factor Value

IC $=$ Total of Core Factor Item

$$
N S F=\frac{\sum N S}{\sum I C}
$$

$\mathrm{NSF}=$ Average Secondary Factor Value

NS = Total of Secondary Factor Value

IS = Total of Secondary Factor Item

The next step is to calculate the overall total value based on the percentage of core factors and secondary factors that can affect the performance of each profile (4):

$$
N=(x) \% N C F+(y) \% N S F
$$

$$
\begin{aligned}
& \mathrm{N}=\text { Total of Aspects Value } \\
& \mathrm{NCF}=\text { Average Core Factor Value } \\
& \mathrm{NSF}=\text { Average Secondary Factor Value } \\
& (\mathrm{x}) \%=\text { Percentage of Core Factor } \\
& (\mathrm{y}) \%=\text { Percentage of Secondary Factor }
\end{aligned}
$$

In the aspect of productivity, determine the percentage value inputted before performing the calculation, where the percentage for the core factor is $100 \%$ due to the aspect of productivity having only one criterion and this value is absolute. In the behavioral aspect, first determine the percentage value entered before making calculations, where the percentage for the core factor is $85 \%$ and the secondary factor is $15 \%$. The last step is a ranking calculation where each alternative candidate is sorted from the largest value to the smallest shown on (5).

$$
\text { Ranking }=(x) \% N p 1+(y) \% N p 2
$$

Np1 = Productivity Value

$\mathrm{Np} 2$ = Behavioral Value

(x) $\%=$ Percentage of Productivity Value

(y) $\%=$ Percentage of Behavioral Value 


\section{Result and Discussion}

\section{A. Profile Matching Calculation on Courier Employees}

Several steps are performed to solve the rewarding problem which can be seen in Figure 1 .

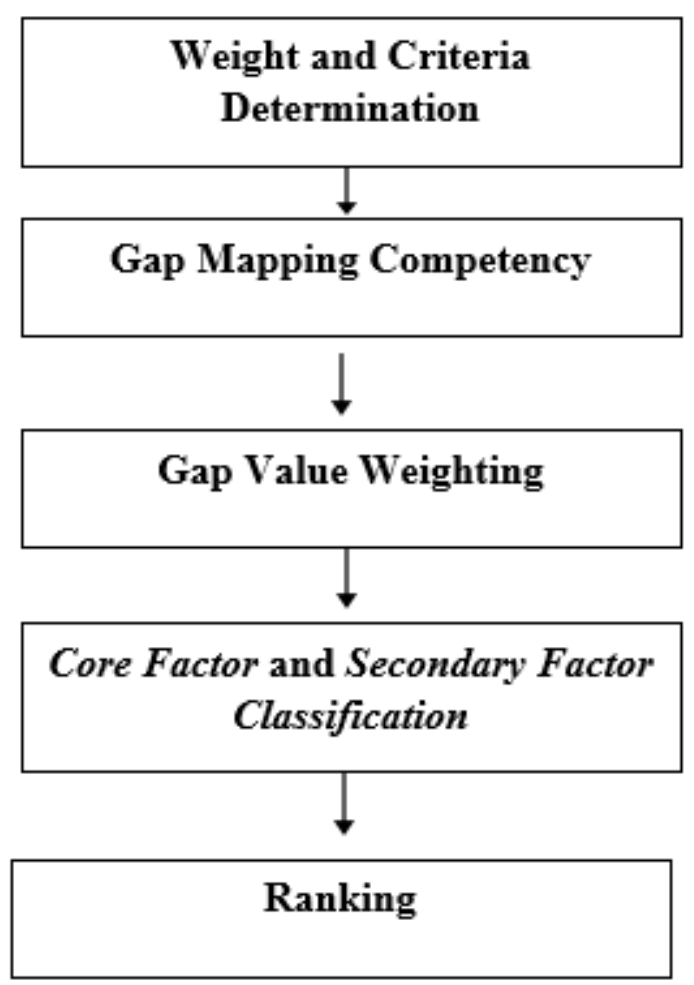

Figure 1: Profile Matching Procedure

Determination of Criteria and Weighting Criteria set in this study are in accordance with those determined by the human resource manager of the company. Two aspects of the assessment are given a weight value in order to facilitate the calculation to determine criteria and weight criteria that can be seen in Table 1.

TABLE I. CRITERIA ASPECT

\begin{tabular}{|c|c|c|c|}
\hline No & Criteria & \multicolumn{2}{|c|}{ Sub Criteria } \\
\hline $\mathbf{1}$ & Productivity & A1 & Absentee \\
\hline \multirow{2}{*}{2} & \multirow{4}{*}{ Behavioral } & B1 & Cnote Success \\
\cline { 3 - 4 } & & B2 & Cash on Delivery \\
\cline { 3 - 4 } & & B3 & Update Status \\
\cline { 3 - 4 } & & B4 & Sign in/out \\
\cline { 3 - 4 } & & B5 & Lateness \\
\hline
\end{tabular}

After determining the aspect criteria, then the sub-criteria aspect value is given, where the value of 5 is the highest value and the value of 1 is the lowest value. This value is obtained based on the results of observation to the company manager that can be seen in Table 2.

TABLE II. EMPLOYEES WEIGHTING

\begin{tabular}{|c|c|c|c|c|c|c|c|c|}
\hline No & $\begin{array}{c}\text { Employee } \\
\text { Name }\end{array}$ & Productivity & \multicolumn{5}{|c|}{ Behavioral Aspects } \\
\hline & & A1 & B1 & B2 & B3 & B4 & B5 & B6 \\
\hline $\mathbf{1}$ & Dasta & 5 & 5 & 4 & 1 & 5 & 5 & 1 \\
\hline $\mathbf{2}$ & M Ridwan & 5 & 1 & 2 & 1 & 5 & 5 & 1 \\
\hline $\mathbf{3}$ & $\begin{array}{c}\text { Sugi } \\
\text { Wahyudi }\end{array}$ & 4 & 1 & 2 & 1 & 5 & 5 & 1 \\
\hline $\mathbf{4}$ & Hadi & 5 & 5 & 4 & 1 & 5 & 5 & 1 \\
\hline. .150 & Saiful Arifin & 3 & 5 & 3 & 1 & 5 & 5 & 1 \\
\hline
\end{tabular}

The GAP referred is a comparison between the difference between the employee's profile value and the standard profile value of the position shown in Table 3.

TABLE III. EMPLOYEES GAP

\begin{tabular}{|c|c|c|c|c|c|c|c|c|}
\hline No & $\begin{array}{c}\text { Employee } \\
\text { Name }\end{array}$ & $\begin{array}{c}\text { Producti } \\
\text { vity }\end{array}$ & \multicolumn{6}{|c|}{ Behavioral Aspects } \\
\hline & & A1 & B1 & B2 & B3 & B4 & B5 & B6 \\
\hline $\mathbf{1}$ & Dasta & 0 & 0 & -1 & -4 & 0 & 0 & -4 \\
\hline $\mathbf{2}$ & M Ridwan & 0 & -4 & -3 & -4 & 0 & 0 & -4 \\
\hline $\mathbf{3}$ & $\begin{array}{c}\text { Sugi } \\
\text { Wahyudi }\end{array}$ & -1 & -4 & -3 & -4 & 0 & 0 & -4 \\
\hline $\mathbf{4}$ & Hadi & - & 0 & -1 & -4 & 0 & 0 & -4 \\
\hline $\mathbf{. 1 5 0}$ & $\begin{array}{c}\text { Saiful } \\
\text { Arifin }\end{array}$ & -2 & 0 & -2 & -4 & 0 & 0 & -4 \\
\hline \multicolumn{2}{|l|}{ Standard Profile Value } & $\mathbf{5}$ & $\mathbf{5}$ & $\mathbf{5}$ & $\mathbf{5}$ & $\mathbf{5}$ & $\mathbf{5}$ & $\mathbf{5}$ \\
\hline
\end{tabular}

The weighting of the GAP Value is performed after each alternative of the best employee candidates get the GAP value, the following is a description of the weight of the GAP value which will be shown in Table 4.

TABLE IV. GAP WEIGHTING

\begin{tabular}{|c|c|c|l|}
\hline No & Gap & $\begin{array}{c}\text { Weight } \\
\text { Value }\end{array}$ & \multicolumn{1}{|c|}{ Remarks } \\
\hline $\mathbf{1}$ & 0 & 5 & Ther is no Gap \\
\hline $\mathbf{2}$ & 1 & 4,5 & Individual excess 1 level \\
\hline $\mathbf{3}$ & -1 & 4 & Individual lack 1 level \\
\hline $\mathbf{4}$ & 2 & 3,5 & Individual excess 2 level \\
\hline $\mathbf{5}$ & -2 & 3 & Individual lack 2 level \\
\hline $\mathbf{6}$ & 3 & 2,5 & Individual excess 3 level \\
\hline $\mathbf{7}$ & -3 & 2 & Individual lack 3 level \\
\hline $\mathbf{8}$ & 4 & 1,5 & Individual excess 4 level \\
\hline $\mathbf{9}$ & -4 & 1 & Individual lack 1 level \\
\hline
\end{tabular}

Table 4 is a description of values as a reference for assessing the weight value so that the scores obtained are in accordance with the GAP of employee competencies. Criteria are grouped based on the main priority (core factor) and supporting criteria (secondary factor) as shown in table 5, table 6, and table 7 .

TABLE V. CORE FACTOR AND SECONDARY FACTOR

\begin{tabular}{|c|c|c|c|c|}
\hline No & Aspect Value & \multicolumn{2}{|c|}{ Criteria } & Factor Type \\
\hline $\mathbf{1}$ & Productivity & A1 & Absentee & Core Factor \\
\hline
\end{tabular}




\begin{tabular}{|c|c|c|c|c|}
\hline \multirow{4}{*}{2} & B1 & Cnote Success & Core Factor \\
\hline \multirow{4}{*}{ Behavioral } & B2 & Cash on Delivery & Core Factor \\
\hline & B3 & Update Status & Core Factor \\
\hline & B4 & Sign in/out & $\begin{array}{c}\text { Secondary } \\
\text { Factor }\end{array}$ \\
\hline & & B5 & Lateness & $\begin{array}{c}\text { Secondary } \\
\text { Factor }\end{array}$ \\
\hline
\end{tabular}

TABLE VI. PRODUCTIVITY GAP WEIGHTING

\begin{tabular}{|c|l|c|c|}
\hline No & Employee Name & $\begin{array}{c}\text { Criteria } \\
\text { A1 }\end{array}$ & NCF \\
\hline $\mathbf{1}$ & Dasta & 5 & 5 \\
\hline $\mathbf{2}$ & M Ridwan & 5 & 5 \\
\hline $\mathbf{3}$ & Sugi Wahyudi & 4 & 4 \\
\hline $\mathbf{4}$ & Hadi Kiswanto & 5 & 5 \\
\hline $\mathbf{5}$ & Saiful Arifin & 3 & 3 \\
\hline
\end{tabular}

TABLE VII. BEHAVIORAL GAP WEIGHTING

\begin{tabular}{|c|c|c|c|c|c|c|c|c|}
\hline \multirow[t]{2}{*}{ No } & \multirow{2}{*}{$\begin{array}{c}\text { Employee } \\
\text { Name }\end{array}$} & \multicolumn{6}{|c|}{ Criteria } & \multirow[t]{2}{*}{ NCF } \\
\hline & & B1 & B2 & B3 & B4 & B5 & B6 & \\
\hline 1 & Dasta & 5 & 4 & 1 & 5 & 5 & 1 & 3,3 \\
\hline 2 & M Ridwan & 1 & 2 & 1 & 5 & 5 & 1 & 1,3 \\
\hline 3 & Sugi Wahyudi & 1 & 2 & 1 & 5 & 5 & 1 & 1,3 \\
\hline 4 & Hadi & 5 & 4 & 1 & 5 & 5 & 1 & 3,3 \\
\hline .150 & Saiful Arifin & 5 & 3 & 1 & 5 & 5 & 1 & 3 \\
\hline \multicolumn{9}{|c|}{$\begin{array}{l}\text { The fina } \\
\text { using th } \\
\text { Table } 8 \text {. }\end{array}$} \\
\hline \multicolumn{9}{|c|}{ TABLE VIII. PROFILE MATCHING RANKING RESULT } \\
\hline No & $\begin{array}{l}\text { Employee } \\
\text { Name }\end{array}$ & Prodi & etivity & & $\begin{array}{l}\text { avior } \\
\text { ect }\end{array}$ & & tal & Rank \\
\hline \multicolumn{2}{|c|}{ Percentage } & \multicolumn{2}{|l|}{$80 \%$} & \multicolumn{2}{|c|}{$20 \%$} & \multirow{2}{*}{\multicolumn{2}{|c|}{\begin{tabular}{|l|}
4.73 \\
\end{tabular}}} & \multirow[b]{2}{*}{1} \\
\hline 1 & $\begin{array}{l}\text { Bima Fitra } \\
\text { Kurniawan }\end{array}$ & \multicolumn{2}{|c|}{5} & \multicolumn{2}{|c|}{3.66667} & & & \\
\hline 2 & Mahpudin & \multicolumn{2}{|c|}{5} & \multicolumn{2}{|c|}{3.58333} & \multicolumn{2}{|c|}{4.72} & 2 \\
\hline 3 & $\begin{array}{l}\text { Ibnu } \\
\text { Mazhun }\end{array}$ & \multicolumn{2}{|c|}{5} & \multicolumn{2}{|c|}{3.58333} & \multicolumn{2}{|c|}{4.72} & 3 \\
\hline 4 & $\begin{array}{l}\text { Eko } \\
\text { Sugiyanto }\end{array}$ & \multicolumn{2}{|c|}{5} & \multicolumn{2}{|c|}{3.58333} & \multicolumn{2}{|c|}{4.72} & 4 \\
\hline 5 & Purwanto & \multicolumn{2}{|c|}{5} & \multicolumn{2}{|c|}{3.58333} & \multicolumn{2}{|c|}{4.72} & 5 \\
\hline
\end{tabular}

\section{B. Decision Support System Implementation Using Profile Matching}

Following the calculation of profile matching method on the research, implementation process is performed out into a system. The following figures is an image of the implementation of profile matching. The framework used for implementation is using PHP Framework and Bootstrap for interface development.

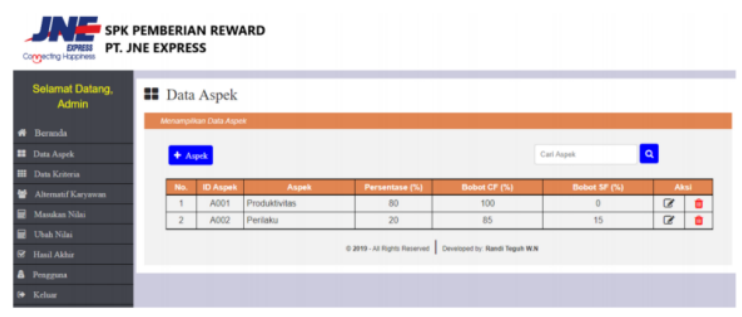

Figure 2: Data Aspect Weighting

Figure 2, is a picture of the system which is used as an input of the Data Aspect. Data Aspects can be inputted are aspects of productivity, aspects of behavior and aspects of integrity.

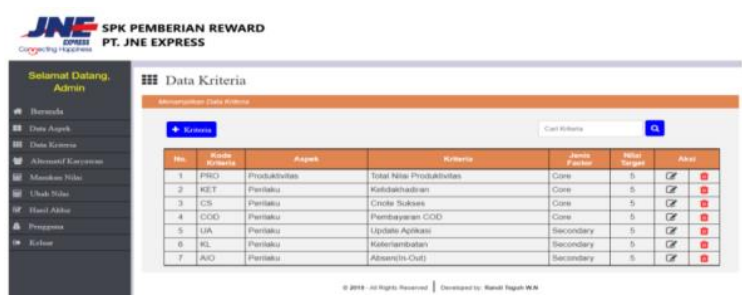

Figure 3: Data Criteria

Criteria Data is a sub of the Aspect Data that has been previously inputted, can be seen from Figure 3, where the Productivity Aspect has criteria Total Value of Productivity with the type of factor, namely the core ,6 factor and has a value target of 5. As for the , 6 Behavioral Aspects it has 6 criteria, namely Absence, ${ }^{3}$ Successful Cnote, COD payment with the type of factor, namely the core factor, and updates Application, Absence (In-Out) and Delay with the type of factor, namely secondary factor. Each criterion has a target value of 5 . Admin can also change and delete aspect data in the Action column.

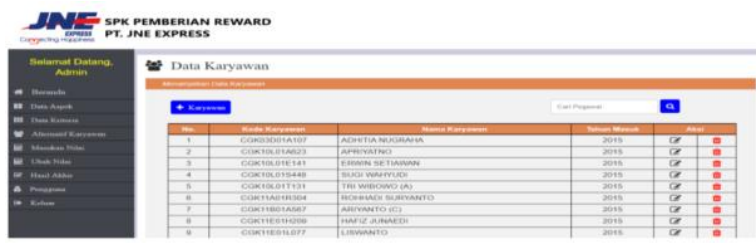

Figure 4: Employee Data

In Figure 4, There are 5 table columns in the Employee Data Menu, namely No, Employee Code, Employee Name, Year of Entry, and Action. Employee data that has been inputted as many as 150 employee data. Admin can edit and delete alternatives employees in the action column.

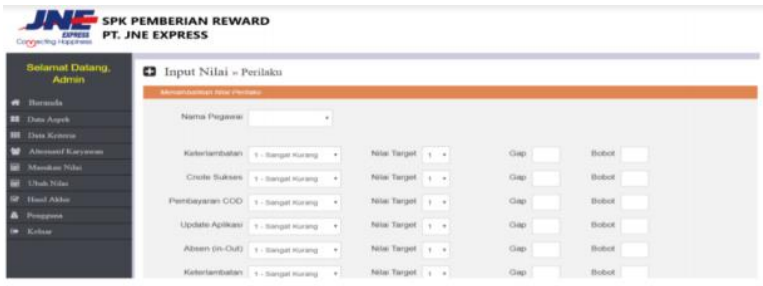

Figure 5: Behavior Aspect Input Data 


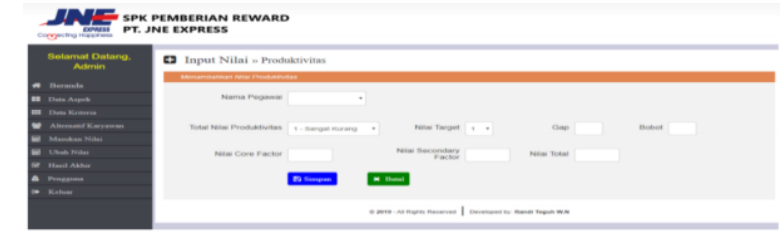

Figure 6: Productivity Aspect Input Data

In Figure 5, and Figure 6 is where productivity aspect and Behavioral Aspect are inputted for later calculation of each Gap.

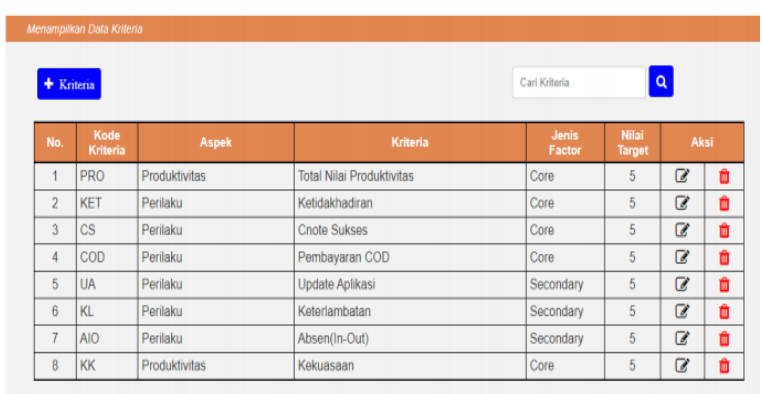

Figure 7: Core Factor and Secondary Factor Weighting

Figure 7, is a picture of the system used to input core factor and secondary factor data. The target value set for all factors is 5 .

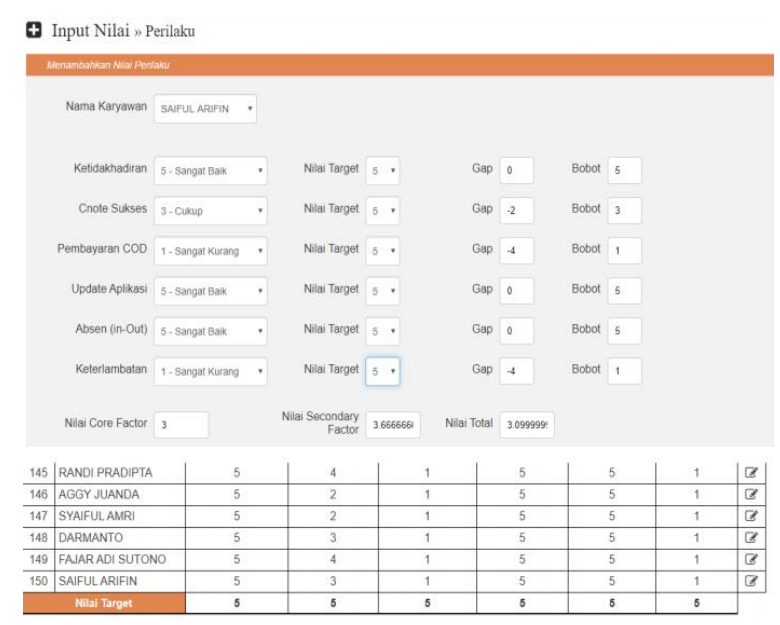

Figure 6: Behavioral Weighting

Figure 6, is a picture of the system used to input the behavior weight value of each employee. Courier Employees at this company are assessed for achievement based on data regularly.

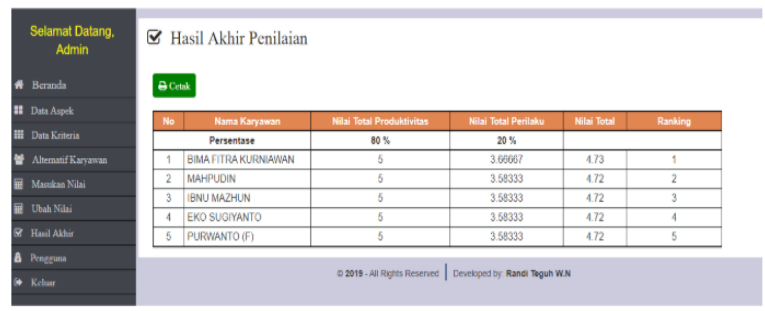

Figure 7: Employee Reward Recommendation

Figure 7 , is the recommendations result provided by the system, where the first rank is Bima Fitra Kurniawan followed by Mahpudin, third rank was obtained by Ibnu Mazhun, the fourth rank was obtained by Eko Sugiyanto and the last rank was obtained by Purwanto.

\section{B. System Validation}

At the validation stage, comparisons will be made between manual calculations with system calculations. This stage aims to find out which method used in accordance with the intended use and always gives results that can be trusted.

TABLE IX. TESTING COMPARISON BETWEEN

\begin{tabular}{|l|l|l|l|l|l|}
\hline No & Name & $\begin{array}{l}\text { Testing } \\
\text { by } \\
\text { Manual }\end{array}$ & No & Name & $\begin{array}{l}\text { Testing } \\
\text { by } \\
\text { DSS }\end{array}$ \\
\hline 1 & Mahpudin & $74,49 \%$ & 1 & $\begin{array}{l}\text { Bima } \\
\text { Fitra }\end{array}$ & 4.73 \\
\hline 2 & Abdullah & $73,80 \%$ & 2 & Saifudin & 4.722 \\
\hline 3 & Saifudin & $73,51 \%$ & 3 & Abdullah & 4.722 \\
\hline 4 & $\begin{array}{l}\text { Dwi } \\
\text { Triyanto }\end{array}$ & $73 \%$ & 4 & Mahpudin & 4.721 \\
\hline 5 & $\begin{array}{l}\text { Ibnu } \\
\text { Mahzun }\end{array}$ & $72,62 \%$ & 5 & $\begin{array}{l}\text { Ibnu } \\
\text { Mahzun }\end{array}$ & 4.721 \\
\hline
\end{tabular}

Table 9, shows the final results of the assessment of 5 employees who have the best value using different methods. The first method namely by doing manual calculations, where the final results are displayed in the form of a percentage. The total value is obtained based on the calculation of Behavioral Aspects only without involving the productivity aspect, which should have value the most important is the productivity aspect. With the second method is by performing system calculations, where this calculation is the Productivity Aspect has a value of $80 \%$ and the Behavioral aspect has a value of $20 \%$ of the total value, so that you get the final result as in table 9.

\section{Conclusions}

Based on the research that has been carried out using the Profile Matching method, its concluded that Profile Matching can produce recommendations for the highest-ranking candidate employees which are obtained by Bima Fitra Kurniawan with a value of 4.73. Then the second rank was obtained by Saifudin with a value of 4.722 . The third rank was obtained by Abdullah with a value of 4.722 . The fourth rank was obtained by Mahpudin with a value of 4.721 , and the last rank was obtained by Ibnu Mahzun with a value of 4.721 . The results provided by the system are able to shorten the decision time in a decision making and 
maintain objectivity in giving rewards to the employee.

\section{Acknowledgment}

We thank to the Program Studi Teknik Informatika Universitas Trilogi which provided the opportunity for researchers to carry out this research.

\section{References}

[1] T. Suryanto, R. Rahim, and A. S. Ahmar, "Employee Recruitment Fraud Prevention with the Implementation of Decision Support System," in Journal of Physics: Conference Series, 2018, doi: 10.1088/1742-6596/1028/1/012055.

[2] I. R. Rahadjeng and A. P. Windarto, "Implementation of Simple Multi Attribute Rating Technique Method using Decision Support System Concept (Case Recommendation of Salon Place in Pematangsiantar City)," IJISTECH (International J. Inf. Syst. Technol., 2019, doi: 10.30645/ijistech.v3i1.29.

[3] B. Arifitama, "Perancangan Sistem Pakar Minat Mahasiswa Berdasarkan Kurikulum Program Studi Teknik Informatika Universitas XYZ," Sisfo, vol. 5, no. 3, 2015, doi: 10.24089/j.sisfo.2015.03.005.

[4] S. D. Handy Permana, K. Bayu Yogha Bintoro, B. Arifitama, A. Syahputra, and M. Cendana, "Improvisation of Minimax Algorithm with Multi Criteria Decision Maker (MCDM) in the Intelligent Agent of Card Battle Game," 2020, doi: 10.1109/icecos47637.2019.8984477.

[5] B. Arifitama, A. Syahputra, S. D. H. Permana, and K. B. Y. Bintoro, "Mobile Augmented Reality for Learning Traditional Culture Using Marker Based Tracking," in IOP Conference Series: Materials Science and Engineering, 2019, doi: 10.1088/1757-899X/662/2/022038.
Sali, and K. D. Schewe, "Accurate and efficient profile matching in knowledge bases," Data Knowl. Eng., vol. 117, no. September 2018, pp. 195-215, 2018, doi: 10.1016/j.datak.2018.07.010.

[7] R. Hidayat, "Menentukan Promosi Jabatan Karyawan dengan Menggunakan Metode Profile Matching dan Metode Promethee," IJSE - Indones. J. Softw. Eng., vol. 2, no. 1, pp. 57-65, 2016.

[8] T. Susilowati, E. Y. Anggraeni, Fauzi, W. Andewi, Y. Handayani, and A. Maseleno, "Using Profile Matching Method to Employee Position Movement," Int. J. Pure Appl. Math., vol. 118, no. 7, 2018.

[9] S. Sunarti, R. Y. Rangga, and Y. N. Marlim, "Application Profile Matching Method for Employees Online Recruitment," in IOP Conference Series: Earth and Environmental Science, 2017, doi: 10.1088/1755-1315/97/1/012035.

[10] S. A. Sitepu, S. Efendi, and Z. Situmorang, "The gap values in the profile matching method by fuzzy logic," in Journal of Physics: Conference Series, 2018, doi: 10.1088/1742-6596/978/1/012061.

[11] B. T. Pratama, S. Rahayu, A. C. Frobenius, and Kusrini, "Comparison of Gap Weighting Methods in a Combination of Profile Matching and Topsis in Decision Support System for Healthy Food Menu," in Journal of Physics: Conference Series, 2018, doi: 10.1088/1742-6596/1140/1/012047.

[12] B. H. Situmorang, E. Pibriana, and E. T. Tosida, "Decision support system for determining Bantuan Siswa Miskin (BSM) receivers with profile matching method," in IOP Conference Series: Materials Science and Engineering, 2018, doi: 10.1088/1757-899X/332/1/012009.

[6] J. Martinez-Gil, A. L. Paoletti, G. Rácz, A. 